\title{
Aspek Hukum Hak Cipta Terhadap Buku Elektronik (E-Book) Sebagai Karya Kekayaan Intelektual
}

\author{
Muchtar Anshary Hamid Labetubun \\ Fakultas Hukum Universitas Pattimura, Ambon, Indonesia \\ E-mail:mahlabetubun@gmail.com
}

\begin{abstract}
Intellectual Property Rights basically have economic value. Therefore it is not excessive if the results of human intellectual work are given adequate legal protection. Through this way Intellectual Property Rights will get a decent place as one form of rights that has economic value. E-Book is included as a protected work because it is an adaptation of the initial creation in the form of a book that each has its own copyright after being realized in a real form.
\end{abstract}

Keywords: Legal aspects, Copyright, Electronic Books.

\section{A. PENDAHULUAN.}

Hak Kekayaan Intelektual (selanjutnya disingkat HKI) berawal dan berkembang dari adanya pemahaman atas perlunya suatu bentuk penghargaan khusus terhadap karya intelektual seseorang dan hak yang muncul dari karya itu. HKI ini baru ada bila kemampuan intekelektual manusia itu telah membetuk sesuatu yang bisa dilihat, didengar, dibaca, maupun digunakan secara praktis. HKI merupakan hak yang berasal dari hasil kegiatan kreatif suatu kemampuan daya pikir manusia yang dieksepsikan kepada khalayak umum dalam berbagai bentuknya, yang memiliki manfaat serta berguna dalam menunjang kehidupan manusia, juga mempunyai nilai ekonomi. ${ }^{1}$ Sifat dari HKI adalah hak kebendaan, yaitu hak atas sesuatu benda yang bersumber dari hasil kerja otak atau hasil kerja rasio, dimana hasil kerja tersebut dirumuskan sebagai intelektualitas, sehingga ketika sesuatu tercipta berdasarkan hasil kerja otak maka dirumuskan sebagai HKI.

Menurut sifatnya hak dalam HKI dapat digolongkan menjadi dua yaitu Hak Ekonomi (Economic Rights) dan Hak Moral (Moral Rights). Hak Ekonomi adalah Hak untuk memperoleh keuntungan atas kekayaan intelektual. Dikatakan Hak Ekonomi karena HKI adalah benda yang

1 Djumhana, Muhammad dan Djubaedillah, R. (2003). Hak Milik Intelektual (Sejarah Teori dan Prakteknya di Indonesia), Bandung: Citra Aditya Bakti, h. 21-22 
dapat dinilai dengan uang. Hak ekonomi tersebut berupa keuntungan sejumlah uang yang diperoleh karena penggunaan oleh pihak lain berdasarkan lisensi. Hak ekonomi itu diperhitungkan karena HKI dapat digunakan / dimanfaatkan oleh pihak lain dalam perindustrian atau perdagangan yang mendatangkan keuntungan. ${ }^{2}$

Tidak semua orang dapat dan mampu memperkerjakan otak (nalar, rasio, intelektual) secara maksimal. Oleh karena itu, tidak semua orang dapat menghasilkan HKI, namun hanya orang yang mampu memperkerjakan otaknya saja yang dapat menghasilkan hak kebendaan yang disebut sebagai HKI. Hasil kerja otak yang membuahkan HKI bersifat eksklusif, dimana hanya orang tertentu saja yang dapat melahirkan hak semacam itu. HKI yang bersifat eksklusif tersebut, merupakan suatu bentuk penghargaan atas hasil intelektualitas manusia (dalam hal ini hasil kerja otak manusia), baik dalam bentuk penemuan-penemuan maupun hasil karya cipta dan seni, terutama ketika hasil kerja otak manusia itu digunakan untuk tujuan komersial. ${ }^{3}$

Salah satu jenis HKI yang secara nyata telah memberikan kontribusi bagi peningkatan kualitas sumber daya manusia adalah karya ilmiah khususnya dalam bentuk buku. Hasil karya ilmiah tersebut dapat ditulis dalam bentuk buku cetak (printed Book) atau pun dalam bentuk buku digital (e-Book) yang berupa file ( $p d f$, doc, txt) dan dapat diunduh serta dibaca melalui perangkat elektronik. Bentuk buku tersebut masing-masing mempunyai keunggulan dan kelemahan. Salah satu keunggulan buku cetak yang beredar di toko buku besar adalah memiliki dan mencantumkan

2 Muhammad, Abdul Kadir. (2007). Kajian Hukum Ekonomi Hak Kekayaan Intelektual, Bandung: Citra Aditya Bakti, h. 23

3 Saidin, OK. (2015). Aspek Hukum Hak Kekayaan Intelektual (Intellectual Property Rights), Jakarta: Raja Grafindo Perkasa, h. 10
International Serial Book Number (yang selanjutnya disebut ISBN). Dengan memiliki ISBN, buku cetak masih terpercaya untuk menjadi acuan akademisi sebagai referensi dalam menyusun karya ilmiahnya. ${ }^{4}$

Buku (apapun jenisnya, baik itu majalah, koran, buku, kitab dan sebagainya) yang selama ini kita jadikan sebagai gudang dari berbagai macam ilmu pengetahuan dan informasi tidak bisa mengelak dari imbas yang diakibatkan dari efek digitalisasi informasi. Imbas dari era digitalisasi informasi terhadap buku, lebih ke arah munculnya versi baru dari buku dalam bentuk digital, yang lebih dikenal dengan sebutan e-book (electronic book atau buku elektronik).

E-book adalah versi elektronik dari suatu buku yang memerlukan suatu media elektronik (komputer/laptop, smartphone, tablet dsb) agar bisa dibaca. Karena e-book adalah benda elektronik (lebih tepatnya benda digital), secara otomatis e-book memiliki sifat-sifat dari benda digital. Salah satu contoh karakteristik utama yang mendukung reproduksi dan persebaran dari benda digital adalah kemudahannya untuk digandakan dan disebarkan (terutama dengan pesatnya penggunaan teknologi internet), karakteristik ini menyebabkan suatu kondisi dimana jumlah peredaran e-book saat ini sangat jauh melampaui jumlah peredaran versi cetak.

Memasuki zaman yang serba digital dan tingginya kebutuhan masyarakat untuk memperoleh serta berbagi ilmu pengetahuan, maka sudah tidak dapat dihindarkan lagi apabila masyarakat dengan bebas saling berbagi buku elektronik, baik secara interpersonal maupun secara terbuka kepada publik melalui website, weblog, atau media sosial pada jaringan Internet, kenyataan

\begin{tabular}{l}
\hline Kusmawan, Denny. \\
Perlindungan Hak Cipta Atas Buku, Jurnal \\
Perspektif, Volume XIX No. 2, h. 137.
\end{tabular}


ini terjadi karena pandangan sebagian masyarakat yang menganggap bahwa kepentingan masyarakat untuk memperoleh akses ilmu pengetahuan seyogianya lebih diprioritaskan dari pada hak-hak pemilik hak cipta, khususnya hak ekonomi. Muncul pendapat bahwa pada dasarnya hak moral yang sesungguhnya lebih utama diinginkan oleh pencipta dari pada hak ekonomi, seperti pendapat Catherine Colston dalam Ignatius Haryanto berikut: ${ }^{5}$

"Dalam konsep hak cipta sebagai bagian dari hak kekayaan intelektual dikenal adanya insentif ekonomi ataupun imbalan atas hasil karya seseorang, namun lebih utama yang diinginkan oleh seorang pencipta adalah reputasi dan integritas karya yang dihasilkan. Ketika sebuah karya ditampilkan kepada publik, sang pencipta ingin agar namanya dilekatkan terus dengan karya yang telah dihasilkan".

Adapun tujuan perlindungan hukum dalam upaya perlindungan hak cipta adalah dalam meningkatkan pendapatan ekonomi sekaligus menumbuh kembangkan kreatifitas pencipta di dalam menciptakan dan menjamin perklindungan karya cipta seseorang terutama dalam bentuk pelanggaran atas karya cipta. Hukum mengakui bahwa hak cipta lahir sejak saat ciptaan selesai diwujudkan. Ciptaan sebagaimana ditegaskan dalam Undang-Undang Hak Cipta adalah hasil setiap karya pencipta dalam bentuk yang khas dan menunjukkan keasliannya dalam lapangan ilmu pengetahuan, seni dan sastra. ${ }^{6}$ Sesuai dengan tujuan dari perlindungan hukum hak cipta yaitu untuk mencegah terjadinya suatu

5 Haryanto, Ignatius. (2014). Sesat Pikir Kekayaan Intelektual, Jakarta: KPG, , h. 80.

6 Rosidi, Ajib. (2002). Undang-Undang Hak Cipta Pandangan Awam, Jakarta: Djambatan, h. 18 . peristiwa hukum yang merugikan pencipta. $^{7}$

Dalam Pasal 40 UUHC, Ciptaan yang dilindungi meliputi Ciptaan dalam bidang ilmu pengetahuan, seni, dan sastra, terdiri atas :

a) Buku, pamflet, perwajahan karya tulis yang diterbitkan, dan semua hasil karya tulis lainnya.

b) Ceramah, kuliah, pidato, dan Ciptaan sejenis lainnya.

c) Alat peraga yang dibuat untuk pendidikan kepentingan pengetahuan.

d) Lagu dan/atau musik dengan atau tanpa teks

e) Drama, drama musikal, tari, koreografi, pewayangan, dan pantomime

f) Karya seni rupa dalam segala bentuk seperti lukisan, gambar, ukiran, kaligrafi, seni pahat, patung, atau kolase

g) Karya seni terapan.

h) Peta.

i) Karya seni batik atau seni motif lain.

j) Karya fotografi.

k) Potret.

1) Karya arsitektur.

m) Karya sinematografi..

n) Terjemahan, tafsir, saduran, bunga rampai, basis data, adaptasi, aransemen, modifikasi dan karya lain dari hasil transformasi.

o) Terjemahan, adaptasi, aransemen, transformasi, atau modihkasi ekspresi budaya tradisional.

p) Kompilasi Ciptaan atau data, baik dalam format yang dapat dibaca dengan Program Komputer maupun media lainnya.

7 Kantaadmadja, Mieke Komar dan Ramli, Ahmad M. (2007). Perlindungan Atas Hak Kekayaan Intelektual Masa Kini Dan Tantangan Menghadapi Era Globalisasi Abad 21, Bandung: Alumni, h. 40 

q) Kompilasi ekspresi budaya tradisional selama kompilasi tersebut merupakan karya yang asli.
r) Permainan video.
s) Program Komputer.

Melihat pada uraian mengenai apa saja yang termasuk ciptaan sebagaimana disebut di atas, dapat dilihat bahwa buku merupakan salah satu ciptaan yang dilindungi, begitupula adaptasi. Dalam bagian Penjelasan Pasal 40 ayat (1) huruf $\mathrm{n}$ UUHC 2014 disebutkan yang dimaksud dengan "adaptasi" adalah mengalih wujudkan suatu ciptaan menjadi bentuk lain. Buku Elektronik (E-Book) juga merupakan Ciptaan yang dilindungi karena merupakan adaptasi dari ciptaan awal berbentuk buku yang masing-masing memiliki hak cipta sendiri setelah diwujudkan dalam bentuk nyata. Hal ini juga sebagaimana disebutkan dalam Pasal 40 ayat (2) UUHC 2014 yang menyatakan: Ciptaan sebagaimana dimaksud pada ayat (1) dilindungi sebagai Ciptaan tersendiri dengan tidak mengurangi Hak Cipta atas Ciptaan asli.

Meskipun Undang-Undang Nomor 28 tahun 2014 tentang Hak Cipta telah memberikan perlindungan hukum terhadap hak cipta, tetapi di dalam pelaksanaannya banyak terjadi pelanggaran-pelanggaran hak cipta dan bagi pelanggaran hak tersebut dapat dituntut atas perbuatannya. Salah satu contoh terjadinya pelanggaran terhadap E-book yaitu dengan cara di bajak dan dijual mulai 2000 di dua akun Instagram ebook_indo dan ebook_novelmurahbngt. Ada beberapa novel terbitan Stiletto Book Group yang juga dijual dan banyak novel-novel best seller dari penerbit lain. Buku e-book bajakkan itu sendiri dihargai Rp. 20.000,- hingga Rp. 100.000,dengan cara membayar pulsa untuk bisa join di salah satun akun media mereka. Biasanya para resseler e-book berjualan di Instagram. Ebook yang mudah dan bisa didapatkan dengan simple di tangan para penikmat ebook dan gratis selama seumur hidup. ${ }^{8}$

Tidak dapat dipungkiri harga buku di toko saat ini memang terbilang mahal bahkan jarang ada diskon atau potongan harga. Kalaupun ada itupun jika toko tersebut sedang ada bazar atau cuci gudang. Akan tetapi para remaja zaman sekarang lebih senang mendapatkan apa pun secara instan (gratis) tanpa memikirkan dampak untuk para penulis yang berjuang demi menerbitkan sebuah karya.

Berdasarkan uraian latar belakang di atas maka penulis tertarik untuk mengkaji permasalahan yang dikaji "Bagaimana pengaturan buku elektronik (e-book) sebagai hak cipta menurut Undang-Undang Nomor 28 Tahun 2014 tentang Hak Cipta".

\section{B. PEMBAHASAN}

Perkembangan teknologi informasi khususnya program komputer dan internet yang demikian pesat telah memberi pengaruh sangat besar terhadap hukum khususnya yang berkaitan dengan industry dan hak cipta. Pada kenyataannya, kesiapan dan pemahaman hukum masyarakat saat ini tampaknya tidak dapat secara penuh mengimbangi akses-akses yang ditimbulkan akibat pemanfaatan teknologi informasi itu. ${ }^{9}$

Buku elektronik (disingkat Buku elektronik atau ebook) atau buku digital adalah versi elektronik dari buku. Jika buku pada umumnya terdiri dari kumpulan kertas yang dapat berisikan teks atau gambar, maka

8 http://headlinebogor.com / uncategorized / pembajakan - merajalela - gramedia - enggan berkomentar. (Diakses Tanggal 4 April 2017).

9 Labetubun, Muchtar A Hamid. (2011). Perlindungan Hukum Desain Industri Di Dunia Maya ( Kajian Overlaping antara Hak Cipta Dengan Hak Desain Industri ). Jurnal Sasi Vol. 17 No. 4. h. 1. 
buku elektronik berisikan informasi digital yang juga dapat berwujud teks atau gambar. Buku elektronik diminati karena ukurannya yang kecil bila dibandingkan dengan buku, dan juga umumnya memiliki fitur pencarian, sehingga kata-kata dalam buku elektronik dapat dengan cepat dicari dan ditemukan.

Terdapat berbagai format buku elektronik yang populer, antara lain adalah teks polos, $p d f$, jpeg, doc lit dan html. Masing-masing format memiliki kelebihan dan kekurangan masing-masing, dan juga bergantung dari alat yang digunakan untuk membaca buku elektronik tersebut. Salah satu usaha untuk melestarikan literature berbentuk buku yang banyak jumlahnya dan memerlukan biaya perawatan yang mahal adalah dengan melakukan transfer dari bentuk buku ke bentuk buku elektronik. Dalam hal ini akan banyak ruang dan juga upaya yang dihemat untuk merawat literatur-literatur tersebut. ${ }^{10}$

Amazon menjadi salah satu perusahaan yang mengembangkan Buku elektronik ini, mereka menggunakan buku elektronik semakin populer karena dapat dibaca kapan saja di mana saja dengan Kindle, salah satu tablet luncuran mereka. Buku elektronik dapat dibuka dengan berbagai macam software diantaranya Adobe Acrobat, Microsoft Word dan masih banyak lagi tergantung format yang dimiliki. ${ }^{11}$

Terdapat berbagai format buku elektronik yang banyak digunakan. Popularitas umumnya bergantung pada ketersediaan berbagai buku elektronik dalam format tersebut dan mudahnya piranti lunak yang digunakan untuk

10 https://id.wikipedia.org / wiki / Buku_elektronik. (Diakses pada tanggal 18 Agustus 2017)

11 Karmawan, I Gusti Made. (2014). Dampak Peningkatan Kepuasan Pelanggan Dalam Proses Bisnis E-Commerce Pada Perusahaan Amazon.Com, Jurnal, ComTech Vol. 5 No. 2. h. 748- 762, membaca jenis format tersebut diperoleh: ${ }^{12}$

1) Teks Polos adalah format paling sederhana yang dapat dilihat hampir dalam setiap piranti lunak menggunakan komputer personal. Untuk beberapa devais mobil format dapat dibaca menggunakan piranti lunak yang harus lebih dahulu diinstal.

2) PDF memiliki kelebihan dalam hal format yang siap untuk dicetak. Bentuknya mirip dengan bentuk buku sebenarnya. Selain itu terdapat pula fitur pencarian, daftar isi, memuat gambar, pranala luar dan juga multimedia.

3) JPEG Seperti halnya format gambar lainnya, format JPEG memliki ukuran yang besar dibandingkan informasi teks yang dikandungnya, oleh karena itu format ini umumnya populer bukan untuk buku elektronik yang memilki banyak teks akan tetapi untuk jenis buku komik atau manga yang proporsinya lebih didominasi oleh gambar.

4) LIT Format LIT merupakan format dari Microsoft Reader yang memungkinkan teks dalam buku elektronik disesuaikan dengan lebar layar mobile device yang digunakan untuk mebacanya. Format ini memiliki kelebihan bentuk huruf yang nyaman untuk dibaca.

5) Docx Format Docx merupakan format dari Microsoft Word yang sangat banyak ditemui sekarang dan tersebar di

12 https://id.wikipedia.org / wiki / Buku_elektronik. (Diakses pada tanggal 17 Agustus 2017) 
Internet, format ini sangat banyak digunakan karena banyaknya pengguna MS Word dan file keluaran yang cukup kecil, selain itu huruf yang lebih variatif membuatnya sangat digemari.

6) HTML Dalam format HTML ini gambar dan teks dapat diakomodasi. Layout tulisan dan gambar dapat diatur, akan tetapi hasil dalam layar kadang tidak sesuai apabila dicetak.

7) Format Open Electronic Book Package Format ini dikenal pula sebagai OPF FlipBook. OPF adalah suatu format buku elektronik yang berbasis pada XML yang dibuat oleh sistem buku elektronik. Buku elektronik dalam format ini dikenal saat FlipBooks sebagai piranti lunak penyaji menampilkan buku dalam format 3D yang bisa dibuka-buka (flipping). Terdapat suatu proyek yang sedang berjalan yang berupaya agar format OPF ini dapat dibaca menggunakan penjelajah Internet standar (semisal: Mozilla, Firefox, atau Microsoft Internet Explorer), tanpa perlu adanya perlengkapan (piranti lunak, plugin) tambahan. Saat ini untuk melihat buku elektronik dalam format OPF sehingga diperoleh rasa benar-benar membuka buku (flipping experience) diperlukan piranti lunak penyaji pada sisi klien atau pengguna.

Sebuah E-book, sebagaimana didefinisikan oleh Oxford Kamus bahasa Inggris, adalah "versi elektronik dari buku cetak yang dapat dibaca pada komputer pribadi atau perangkat genggam yang dirancang khusus untuk tujuan ini". "E-Book adalah representasi elektronik dari sebuah buku yang biasanya diterbitkan dalam bentuk tercetak namun ini berbentuk digital". E-Book memiliki dua sifat penting yaitu pertama, E-Book berbentuk digital. Kedua, E-Book membutuhkan alat baca khusus. E-book didedikasikan bagi mereka para pembaca media elektronik atau perangkat $E$-book baik melalui komputer atau bisa juga melalui ponsel yang dapat digunakan untuk membaca buku elekronik ini. ${ }^{13}$

Buku elektronik menawarkan kemungkinan kreasi untuk perluasan akses sebagai halnya dengan perubahan perilaku pembelajaran dan penelitian akademik. Konten E-book dapat selalu diakses tanpa menghiraukan waktu dan tempat, dapat dibaca pada PC (personal computer) atau melalui alat baca buku yang mudah dibawa-bawa (portable). E-book memiliki kelebihan dalam hal accessibility, functionality, and cost-effectiveness. Oleh karena kelebihan yang ada pada e-book, maka tidak mengherankan jika saat ini banyak di kalangan kaum akademisi menjadikan E-book sebagai salah satu ke dalam pengalaman informasi dan kebiasaan penelitian mereka. Hal ini dibuktikan melalui survey yang dilakukan oleh pihak Springer pada tahun 2008 dilaporkan bahwa pengguna kebanyakan mengakses E-book untuk tujuan penelitian dan kajian dan jenis eBook yang sering digunakan adalah karya-karya rujukan (reference works) dan buku teks (textbooks). Dan

13 T.K.N, Diah. (2011). Pelayanan Informasi pada Perpustakaan Badan Kepegawaian Negara (BKN), Skripsi, Jurusan Ilmu Perpustakaan, Jakarta: UIN Syarif Hidayatullah, h. 32 . 
kebanyakan pengguna mendapatkan E-book melalui mesin penelusuran umum seperti Google dan juga melalui catalog perpustakaan online. Di antara pengguna ada yang menyukai E-book, tetapi di sisi lain juga masih banyak pengguna yang lebih menyukai pemakaian buku tercetak (print books) karena memiliki kelebihan dalam kemudahan dan kenikmatan dalam membaca (ease and enjoyability of reading), di samping itu pengguna tidak memiliki keahlian.

Michael Hart dan Proyek Gutenberg-nya adalah pionir yang mengupayakan penggunaan teknologi digital untuk bahan-bahan tekstual. Dia memulai proyeknya tahun 1971 dengan mendigitalkan Declaration of Independence (proklamasi kemerdekaan AS) memakai standar yang dikenal dengan nama American Standard Code for Information Interchange (ASCII). Teknologinya masih sederhana dan tanpa pertimbangan keindahan tampilan seperti yang sekarang dapat dilakukan dengan berbagai program pengolah kata. Tujuannya memang juga sederhana: menyediakan sebanyak mungkin teks digital kepada masyarakat umum. Buku yang dibuat menjadi digital kepada katagori: (a) buku sastra "ringan" seperti Alice in Wonderland, (b) buku sastra berat seperti karya-karya Shakespeare, dan (c) buku-buku rujukan seperti almanak, ensiklopedia, dan kamus.

Setelah teknologi scanner berkembang, kepustakawanan dapat memesan replica dari buku-buku yang sudah tidak dicetak lagi (out-of-print). Beberapa perusahan penerbitan, seperti Replica Books dan Ingram's Lighting Source lalu mulai menyediakan teks digital atau hasil scan dari halaman-halaman buku yang sudah tidak dicetak lagi. Sewaktu teknoogi CD - ROM telah stabil, maka semakin banyak tersedia teks digital dari keseluruhan buku. Produsen mulai memanfaatkan pula teknologi temu-kembali sehingga e-book memiliki kelebihan daripada buku cetak dalam hal kemudahan mencari kata tertentu atau berpindah-pindah halaman. Namun, antarmuka dari e-book ini tetap kurang menarik dan menyulitkan pembaca menikmati isi buku senikmat kalau mereka membaca buku tercetak. Ketika kecepatan transfer di Internet meningkat, maka e-books pun disebarkan lewat "jalur cepat"e ini. Perkembangan teknologi e-books ini tentu saja memerlukan berbagai praktik baru dalam kepustakawanan. Walau bagaimanapun, pustakawan harus seksama memperhatikan perkembangan e-journal dan e-books agar dapat menyusun rencana antisipatif jika suatu saat kebutuhannya semakin meningkat.

Pemerintah

Indonesia

mengharapkan masyarakat Indonesia adalah masyarakat berbasis pengetahuan karena hal ini merupakan misi kebijakan strategi nasional yaitu dalam rangka mewujudkan masyarakat Indonesia yang cerdas, kreatif, dan kompetitif dalam peradaban berbasis pengetahuan. Tahap implementasinya antara lain lewat penguasaan pengetahuan, peningkatan kemampuan pengambil keputusan untuk menyerap pengetahuan, menambah anggaran pendidikan, meningkatkan kurikulum pro pengetahuan, dan membangun sistem birokrasi yang merangsang masyarakat berkreasi dan berinovasi. Faktor-faktor yang mendukung harapan pemerintah tersebut mulai di tandai dengan banyaknya lembaga/instansi maupun perorangan yang muncul dengan menyediakan layanan sumber data untuk berbagai kebutuhan akan referensi ilmu pengetahuan, dalam hal ini berupa referensi ilmiah tentulah sangat membantu bagi siapa saja yang butuh akan suatu referensi untuk menambah pengetahuannya mengenai suatu hal.

Sumber buku elektronik yang sah di Indonesia, antara lain dirilis oleh 
Departemen Pendidikan Nasional dengan dibukanya Buku Sekolah Elektronik (BSE). BSE adalah buku elektronik sah dengan lisensi terbuka yang meliputi buku teks mulai dari tingkatan dasar sampai lanjut. Buku-buku di BSE telah dibeli hak ciptanya oleh pemerintah Indonesia melalui Depdiknas, sehingga bebas diunduh, direproduksi, direvisi serta diperjualbelikan tetapi dengan batas atas harga yang telah ditentukan. Lebih dari itu, seluruh buku ini telah dinilai dan lolos saringan dari penilai di Pusat Kurikulum dan Perbukuan, Badan Penelitian dan Pengembangan, Kementerian Pendidikan dan Kebudayaan.

Lembaga Ilmu Pengetahuan Indonesia juga menyediakan sarana bagi penulis dan publik untuk membuka akses atas aneka buku elektronik dengan lisensi terbuka. Sarana ini telah dibuka dengan nama Buku elektronik. Selain untuk buku-buku ilmiah, buku elektronik juga ditujukan untuk buku 'pembelajaran ilmiah', seperti diktat, buku teks, dll. Di awal tahun 2000 ketika Raksasa teknologi Amerika, Microsoft mulai mengalihkan seluruh buku di Perpustakaan Kongres Amerika ke dalam bentuk digital. Perpustakaan terbesar di dunia ini memiliki 115 juta koleksi buku, majalah, jurnal, dalam 450 bahasa. Hal ini tentu saja menjadi terobosan yang membuat orang tak perlu berlelah-lelah menuju perpustakaan untuk mengkaji dan mencari referensi. Keputusan Microsoft ini cukup beralasan karena minat "membaca" buku, yang mempertemukan penerbit dan konsumen, kian membesar. ${ }^{14}$

Namun, disisi lain mendatangkan buku secara fisik selalu menjadi masalah. Misalnya, buku hilang, atau rusak. Tidak hanya itu penyebaran informasi dan pengetahuan yang berasal dari buku-buku dari belahan Eropa dan Amerika sering mengalami

14 http://www.buku-e.lipi.go.id / utama.cgi ? artikel\&1321295564\&\&1. (Diakses pada tanggal 18 Agustus 2017). keterlambatan untuk tiba di negara-negara Asia dan Afrika. Microsoft sebenarnya bukanlah pemain pertama yang melansir buku elektronik. Sekitar akhir tahun sembilanpuluhan menjelang tahun 2000, ebookcentral.com, Nuvo Media, dan Soft Book Press sudah memulai bahkan menerbitkan perangkat Buku Elektronik. Tetapi karena pada saat itu banyak penerbit yang tidak tertarik membuat buku edisi digital membuat Nuvo Media dan Soft Book Press harus menjual Rocket Book yang menjadi perangkat pembaca Buku Elektronik seharga US\$ 199 dari harga awalnya. US\$ 300, tidak hanya itu keberadaan dua perusahaan tersebut terpaksa harus dibeli Gemstar International dari TV Guide. ${ }^{15}$

Pada perkembangan berikutnya, Adobe, yang terkenal dengan perangkat Fotosoft untuk mengatur tampilan foto, mengeluarkan Acrobat Reader. Perangkat baca ini bisa diperoleh di homepage-nya Adobe.com secara gratis. Adobe juga telah mengembangkan fitur tambahan bernama CoolType, dengan fasilitas ini memungkinkan tampilan buku bisa dibaca pada layar LCD (liquid central display). Layar inilah yang kini digunakan banyak penyedia komputer genggam. Saat ini pengguna Android juga ikut dimanjakan dengan aplikasi untuk membaca buku yang bernama Aldiko Book Reader. Bahkan kini Aldiko telah mencapai versi ke 2. Pada Aldiko Book Reader 2.0, diperubahan dilakukan terutama di bagian user interface, dimana pengguna dapat dengan mudah melakukan akses ke buku-buku terbaru dan best-sellers, pilihan font yang lebih baik, rendering teks dan tipografi yang lebih baik, dan masih banyak kenyaman yang diperoleh bagi pengguna android. ${ }^{16}$

Ada tiga catatan yang patut dibuka untuk melihat perkembangan Buku

15 http://www.buku-e.lipi.go.id / utama.cgi ? artikel\&1321295564\&\&1. (Diakses pada tanggal 18 Agustus 2017).

16 Ibid 
Elektronik di dunia, tidak hanya rintisan awal tetapi sejumlah keberhasilan yang telah dilakukan pada tiga tempat berikut ini: Project Gutenberg, merupakan layanan buku digital terbesar dan tertua yang mendukung free Buku Elektronik. Hingga saat ini terdapat lebih dari 25.000 buku digital yang dengan mudah ditemukan dalam katalog onlinenya. Lalu arXiV yang terdapat di Universitas Cornell. Fasilitas ini memberikan akses secara terbuka terhadap 368.128 referensi elektronik dalam bidang fisika, matematika, sains komputer dan biologi kuantitatif. Hal ini didasarkan pada niat sejumlah ilmuwan yang peduli dengan penyebaran ilmu pengetahuan untuk masyarakat umum secara bebas. Dahulu para ilmuwan tersebut menyajikan karyanya dalam jurnal elektronik bergengsi dan berbayar, namun kini telah digratiskan begitu juga dengan buku-buku hasil terbitan para ilmuwan tersebut. Kemudian adanya proyek sejuta buku atau yang dikenal dengan The Million Book Project. Proyek ini dikembangkan oleh Universal Library, yang merupakan sebuah perpustaaan digital dengan dipelopori oleh Universitas Carnegie Mellon di Amerika Serikat, universitas Zhejiang di China, Institut Sains di India, dan perpustakaan Alexandria di Mesir. Proyek ini memuat referensi dalam 16 bahasa dan koleksi bukunya sudah ada sejak terbitan abad $16 .^{17}$

Hingga saat ini industri buku elektronik di seluruh penjuru dunia belumlah semapan buku konvensional walaupun penjualan Buku Elektronik di Amerika Serikat menunjukkan keunggulan di bandingkan buku cetak. Tren positif ini ternyata mampu membawa jaringan penerbit dan penyedia jasa buku elektronik yang dulunya seringkali kurang responsif terhadap pembeli kini mulai menunjukkan keseriusannya.
Hukum berfungsi sebagai alat perlindungan kepentingan manusia, agar kepentingan manusia itu terlindungi, sehingga hokum harus dilaksanakan. Pelaksanaan hukum dapat berlangsung secara normal, damai, tetapi dapat juga dapat terjadi karena pelanggaran hukum. Hukum yang telah dilanggar itu harus ditegakkan, melalui penegakan hukum inilah hukum itu menjadi kenyataan. ${ }^{18}$

Hak cipta merupakan hasil atau penemuan yang merupakan kreativitas manusia di bidang seni, sastra dan ilmu pengetahuan. Masalah hak cipta adalah masalah yang sangat luas, karena tidak saja menyangkut hak-hak individu yang berada dalam lingkungan nasional, namun ia sudah merupakan masalah yang sudah menyebar dan pembahasan dalam lingkungan internasionai. ${ }^{19}$ Pengaturan hukum terhadap hak cipta sesungguhnya merupakan pengakuan terhadap hak eksklusif, yaitu hak untuk menikmati sendiri manfaat ekonomi pada ciptaan, dengan mengecualikan orang lain yang tanpa persetujuannya untuk turut menikmatinya. Hukum melindungi monopoli serupa itu dan mencegah orang lain mengambil manfaat dari ciptaannya secara tidak adil. Pencipta dapat menikmati sendiri hasil jerih payahnya tanpa gangguan apapun yang dapat merugikan kepentingannya dengan monopoli. Kekuatan proteksi monopoli itu yang diharapkan menjadi insentif untuk memacu kreativitas dan berkembangnya daya inovasi masyarakat, sehingga dapat melahirkan ciptaan-ciptaan baru yang lebih banyak dan beragam. Setidaknya ada beberapa alasan mengapa begitu pentingnya bagi seluruh pihak di Indonesia untuk

18 Hasibuan, Otto. (2008). Hak Cipta Di Indonesia, Tinjauan Khusus Hak Cipta Lagu, Neighbouring Rights, dan Collecting Society, Bandung: Alumni, h. 250.

19 Labetubun, Muchtar A H dan Fataruba, Sabri. (2016). Peralihan Hak Cipta Kepada Ahli Waris Menurut Hukum Perdata, Jurnal Sasi Vol. 22 No. 2. h. 2. 
memberi perhatian serius terhadap hak cipta, yaitu: ${ }^{20}$

1) Hak cipta mengandung budaya berpikir rasional, budaya berpikir kreatif, budaya bekerja dan berkarya, dan budaya menghormati karya atau jerih payah orang lain. Macam-macam budaya itu sangat diperlukan jika ingin membangun masyarakat atau negara maju.

2) Perkembangan dunia telah memasuki babak baru bahwa barang-barang ber HKI umumnya dan ber-hak cipta khususnya sudah menjadi komoditi yang bernilai tinggi secara ekonomi. Semakin banyak negara menghasilkan barang ber-hak cipta semakin besar peluang meningkatkan devisa negara. Pada masa sekarang maupun yang akan datang, Indonesia tidak dapat lagi hanya mengandalkan komoditi ekspor yang bersumber dari (hasil) alam. Sumber daya alam itu terbatas dan suatu saat akan habis.

3) Lahirnya WTO yang diikuti dengan TRIPs merupakan genderang persaingan bebas, bahkan pertarungan satu lawan satu antarnegara, dan secara riil adalah persaingan antar manusia. Kecerdasan, kreativitas, dan kecepatan bertindak manusia adalah kunci memenangkan persaingan. Apabila bangsa kita tetap tidak concern dengan budaya hak cipta, selamanya budaya mencipta (yang membutuhkan kecerdasan, kreativitas, dan kecepatan bertindak) tidak akan

${ }^{20}$ Hasibuan, Otto. Op. Cit, h. 261 berkembang di Indonesia. Jika budaya mencipta tidak berkembang, seterusnya bangsa kita hanya menjadi pembeli atau konsumen produk-produk asing (Eropa, Amerika, Jepang, Korea, dan lain-lain) seperti selama ini.

\section{Berlakunya UUHC 2014} merupakan suatu penyempurnaan yang dilakukan terhadap undang-undang sebelumnya. Tujuan dari penyempurnaan ini tentunya diarahkan pada perlindungan yang lebih baik yang diberikan terhadap pencipta dan ciptaannya. Perkembangan yang semakin pesat dalam bidang ilmu pengetahuan, teknologi, seni dan sastra menimbulkan kebutuhan akan adanya peningkatan perlindungan dan jaminan kepastian hukum bagi pencipta, pemegang hak cipta, dan juga pemilik hak terkait. Turut sertanya Indonesia dalam berbagai perjanjian internasional di bidang hak cipta dan hak terkait juga mendorong Indonesia untuk mengaplikasikannya secara lebih lanjut dalam sistem hukum nasional, agar para pencipta dan kreator nasional mampu berkompetisi dalam jangkauan internasional. Hal ini juga termasuk dalam beberapa latar belakang lahirnya UUHC 2014 menggantikan Undang-Undang Nomor 19 Tahun 2002 tentang Hak Cipta. Dari penjelasan tersebut dapat dilihat bahwa tujuan dari lahirnya undang-undang tersebut secara nyata adalah untuk memberi perlindungan yang lebih baik terhadap pencipta. Hal ini dapat dilihat dari pasal-pasal dalam undang-undang tersebut yang menunjukkan keseriusan perlindungan yang diberikan terhadap pencipta, pemegang hak cipta dan pemilik hak terkait.

Implementasi dari UUHC 2014 belum banyak yang dapat dilihat secara nyata dalam penegakan hukum di Indonesia. Hal ini disebabkan 
undang-undang ini masih baru diberlakukan sejak akhir tahun 2014. Namun secara teori dapat dilihat gambaran dari pemberlakuan undang-undang ini dalam melindungi hak-hak para pihak dalam hak cipta di Indonesia. Terdapat beberapa perubahan dalam UUHC 2014 antara lain adanya perlindungan hak ekonomi dan hukum pencipta serta industri teknologi informasi dan komunikasi, dimana pada undang-undang terdahulu masalah hak ekonomi diletakan pada bagian umum penjelasan. Sedang dalam UUHC 2014 ini, hak ekonomi pencipta atau pemegang hak cipta diatur dalam pasal khusus yakni Pasal 8-11 UUHC 2014, hak ekonomi dalam Pasal 12-15 UUHC 2014 yang pengalihannya diatur dalam Pasal 16-19 UUHC 2014. Demikian dalam jangka perlindungan, juga mengalami perubahan yang signifikan dimana dalam UUHC 2014 diberikan seumur hidup dan 70 tahun sesudah meninggal, sedangkan dalam Undang- Undang Nomor 19 Tahun 2002 tentang Hak Cipta hanya diberikan tambahan selama 50 tahun setelah meninggal.

\section{PE N U T P}

Berdasarkan permasalahan yang dikaji mengenai pengaturan buku elektronik (e-book) sebagai hak cipta menurut Undang-Undang Nomor 28 Tahun 2014 tentang Hak Cipta, maka kesimpulannya bahwa buku elektronik atau e-book merupakan karya kekayaan intelektual yang dilindungi sebagai hak ekslusif pencipta sebagaimana yang diatur di dalam Undang-Undang Hak Cipta Nomor 28 Tahun 2014 tentang Hak Cipta, apabila terdapat pihak yang melakukan pelanggaran hak eksklusif maka pemegang hak cipta dapat menggugat pihak yang melanggar UUHC ke Pengadilan Niaga.

\section{DAFTAR PUSTAKA}

Djumhana, Muhammad dan Djubaedillah, R. (2003). Hak Milik Intelektual (Sejarah Teori dan Prakteknya di Indonesia), Bandung: Citra Aditya Bakti.

Hasibuan, Otto. (2008). Hak Cipta Di Indonesia, Tinjauan Khusus Hak Cipta Lagu, Neighbouring Rights, dan Collecting Society, Bandung: Alumni.

Haryanto, Ignatius. (2014). Sesat Pikir Kekayaan Intelektual, Jakarta: KPG.

Kantaadmadja, Mieke Komar dan Ramli, Ahmad M. (2007). Perlindungan Atas Hak Kekayaan Intelektual Masa Kini Dan Tantangan Menghadapi Era Globalisasi Abad 21, Bandung: Alumni.

Muhammad, Abdul Kadir. (2007). Kajian Hukum Ekonomi Hak Kekayaan Intelektual, Bandung: Citra Aditya Bakti.

Rosidi, Ajib. (2002). Undang-Undang Hak Cipta Pandangan Awam, Jakarta: Djambatan.

Saidin, OK. (2015). Aspek Hukum Hak Kekayaan Intelektual (Intellectual Property Rights), Jakarta: Raja Grafindo Perkasa.

\section{Lain-Lain}

Kusmawan, Denny. (2014). Perlindungan Hak Cipta Atas Buku, Jurnal Perspektif, Volume XIX No. 2.

Karmawan, I Gusti Made. (2014). Dampak Peningkatan Kepuasan Pelanggan Dalam Proses Bisnis E-Commerce Pada Perusahaan Amazon.Com, Jurnal, ComTech Vol. 5 No. 2.

Labetubun, Muchtar A Hamid. (2011). Perlindungan Hukum Desain Industri Di Dunia Maya ( Kajian Overlaping antara Hak Cipta Dengan Hak Desain Industri). 
Jurnal Sasi Vol. 17 No. 4.

Labetubun, Muchtar A H dan Fataruba, Sabri. (2016). Peralihan Hak Cipta Kepada Ahli Waris Menurut Hukum Perdata, Jurnal Sasi Vol. 22 No. 2.

T.K.N, Diah. (2011). Pelayanan Informasi pada Perpustakaan Badan Kepegawaian Negara $(B K N)$, Skripsi, Jurusan Ilmu Perpustakaan, Jakarta: UIN Syarif Hidayatullah.

http://headlinebogor.com / uncategorized / pembajakan - merajalela gramedia - enggan - berkomentar.

https://id.wikipedia.org / wiki / Buku elektronik.

https://id.wikipedia.org / wiki / Buku_elektronik.

http://www.buku-e.lipi.go.id / utama.cgi ? artikel\&1321295564\&\&1. 